\title{
1. Introduction: the globalization of accounting
}

The financial crisis of 2007-09 is frequently referred to as the most drastic and consequential episode in more than two generations. Housing prices plummeted, banks were taken over or went bankrupt, and production declined in many countries. Many people lost their jobs and sweeping austerity measures are likely to affect public spending for years to come. The financial sector was hit particularly hard. Some institutions took excessive risks and experimented with complex and opaque products they were illequipped to handle. The interbank market dried up, and even bank runs made front-page news. Vibrant discussions of the reasons soon emerged and brought to prominence an aspect of financial market regulation that had previously been discussed only among experts: Accounting rules now became the object of heated debate. Off-balance sheet accounting and the procyclical characteristics of fair value accounting were quickly identified as one important cause of the financial crisis. Moreover, more than just accounting rules were criticized. The G20 questioned the governance structures for standard setting in international accounting and called for immediate actions. In particular, it asked the standardization body to review its membership, to enhance transparency, and to ensure appropriate relationships with public authorities (G20, 2008, p. 6). Political reactions to the financial crisis moved accounting standards and transnational standardization bodies into a spotlight that they had successfully avoided for decades.

For most of the time, accounting regulation had been the business of practitioners and experts. Once a federation of national associations, today's International Accounting Standards Board (IASB) is a private standard-setting body with more than 100 employees and an annual budget exceeding $£ 12$ million sterling. Since 1973 it has been in charge of producing a coherent set of international standards. Over the years, the IASB has been asked by many jurisdictions to develop standards for listed companies filing financial statements. Even before the financial crisis, criticism had mounted and the IASB's private governance structure was challenged despite increasing diffusion of its standards. However, the heated debate over IASB and its standards can also be taken as a sign of 
the organization's relevance in regulating cross-border capitalism. It is this core position and the economic and political implications of private standardization that make the IASB a worthwhile object of study. As will become clear, there are no simple explanations for the rise and dominance of the IASB and its standards today. Instead, I present a comprehensive and historically informed approach to understanding organizational developments, rule setting procedures, and dominant actor coalitions.

IASB's uniqueness among international standard setters is widely acknowledged. Out of the 12 key standards identified by the Financial Stability Board (FSB) as ensuring a stable and well-functioning financial system, only those relating to accounting and auditing are set by private bodies (FSB, 2011). Other rules are drafted by intergovernmental organizations, such as the International Monetary Fund (IMF) or IOSCO, the International Organization of Securities Commissions. In accounting and auditing, however, professional actors dominate. Auditing standards are set by the International Federation of Accountants (IFAC), the accountancy profession's global organization. In accounting, the IASB is the center of a regulatory network orchestrating a multitude of actors.

The distinct features of international accounting standardization have increasingly become an object of academic interest. Different interpretations are placed on the emergence of the IASB and the contribution of this private standard-setting body to the harmonization of rules for financial reporting. A more detailed discussion of different approaches follows in Chapter 2, but a number of strands stand out. First and foremost, there are functionalist accounts that argue in favor of a coherent set of standards as a necessary condition for cross-border capital mobility. These perspectives are prominent among accounting studies where much of the debate centers around accounting standards as a means of facilitating (or impeding) information flows between firms and providers of capital. Frequently, the IASB and its standards are considered to be a good, under current conditions perhaps even optimal, solution to overcoming information asymmetries. The organization's capital-market orientation and its close liaison with business are praised as a lean and responsive way of practical problem-solving. Catering to the information needs of capital market actors and allowing them to engage with a private regulatory body are frequently interpreted as functionally adequate means of providing corporate information (cf. Nobes and Parker, 1985, 2004; Sunder, 2002). Political approaches have placed accounting standardization in the wider ambit of regulating global capitalism. The IASB and its success are interpreted as a function of US American financial market dominance (Simmons, 2001) or as a compromise of transatlantic bargaining processes (Posner, 2010). Complementary works on private authority have outlined 
how professional actors and business interests have concurred in the establishment of a private self-regulatory regime, drawing on specialized expertise and catering largely to the interests of globally active businesses (Porter, 2005; Nölke and Perry, 2007).

All of these perspectives have some merit and contribute to understanding the IASB's role in global financial market regulation. However, they only touch upon selected aspects of private global accounting regulation and often fail to give a coherent and discrete explanation of the IASB's emergence and the diffusion of its rules. What is missing so far is a broad analysis of historical developments and organizational characteristics bringing together the approaches mentioned above. This book intends to give such a comprehensive account linking different theoretical perspectives and discussing the sociological underpinnings. It presents a reconstruction of the developments in private accounting regulation at the transnational level. In particular, the book focuses on organizational characteristics to capture the complexity of this process. Furthermore, the case of international accounting regulation permits us to derive lessons about processes of transnational institution building in general. The longterm perspective applied here reveals mechanisms of institution building beyond the nation state, which is characterized by private and public actors from numerous jurisdictions struggling over rules and procedures.

The IASB and its transformation over more than three decades are at the heart of this book. It considers the actors' motives and the conditions they face in establishing and shaping rule setting beyond the nation state. In particular, I answer the following questions in this book: How can the emergence of a private regulator be characterized and explained? What are the mechanisms underlying transnational standardization in accounting? Who are the core actors, and how did they influence developments? Finally, what more general conclusions can be drawn to inform future research into financial market regulation, with particular regard to transnational institution building?

In the remainder of this chapter, I will give a brief introduction to the IASB and its normative foundations, outline the content of the book, provide some relevant background information on the societal relevance of accounting standardization, and discuss the global diffusion of standards.

\subsection{CONTENT OF THE BOOK}

Attempts at standardizing accounting rules started decades ago. In most cases, professionals and their associations played a crucial role. Today's 
IASB is built on these efforts, making it a unique case of a private rulesetting organization that develops quasi-binding standards for the world's capital markets. Over recent decades, the IASB has developed a broad set of standards to foster the global harmonization of financial market information. Its standards, known as International Accounting Standards (IAS) and International Financial Reporting Standards (IFRS), are used by thousands of corporations in more than 100 countries when preparing financial reports. What is now the IASB was founded in the early 1970 s and the organization has been an object of controversy ever since. ${ }^{1}$ In addition to the organizational design, the content of standards has also been disputed even though market logic has always played a prominent role. Today, a clear-cut orientation toward market values, in particular fair value accounting, dominates. In practice, market prices are interpreted as 'fair values,' triggering prompt adjustments in financial reports, thus introducing an element of procyclicality into corporate statements.

The IASB and its embeddedness in a wider, transnational regulatory network are at the heart of this book. Not only has the content of rules been contested, the organizational structure and composition of its decision-making bodies have also been the object of bargaining and interest group politics. As a result of these interactions, the IASB is more than a transnational arena for standard setting. Over time, it has acquired the properties of an actor in its own right and has turned into a core player in regulating accounting at the transnational level. In this analysis, I will take up earlier work, which has pointed out the importance of interests in standard setting, and go one step further to not only provide a detailed characterization of the organization's current configuration but also shed light on the political character of organizational structures and standard setting procedures and elucidate the contested nature of accounting regulation. Demonstrating the political nature of the standard setting endeavor and its organizational representation is the main goal of the book.

Studying how actors shape rule setting beyond the nation state is central to this longitudinal analysis. A process perspective allows us to grasp the dynamics of transnational institution building and also take into account unintended consequences, paradoxical effects, and power struggles. In the final chapter, I will propose an institutionalist interpretation of the empirical findings, arguing that a transnational regulatory path has emerged that is dominated by the IASB and certain actor constellations. Hence, a precise characterization of these constellations is one key aspect of the study. Some of the positions within the wider regulatory network are predefined by the IASB's constitution, which puts particular emphasis on the expertise shared by accounting practitioners. Professional competence and practical experience are key qualifications expected of the members of 
the organization's board who are engaged in standard setting, as well as of the foundation's trustees tasked with overseeing standardization activities.

Accounting standards are predominantly concerned with offering a framework that allows corporate information to be translated into numbers. Measurable and calculable constructs give an indication of a company's economic performance. At the firm level, the availability of comparable, reliable, and meaningful financial information is a key requisite to attract external investment. Multinational corporations use financial reports to frame performance according to numerical logics and to address the information needs of third parties. Publishing annual reports, however, is more than a legal requirement. It also permits the presenting of financial and other information to specifically address the needs of shareholders and other capital providers. In addition, the needs of other stakeholders, tax authorities, and other interested parties are addressed. Listed corporations therefore use financial reporting to paint a picture of the organization's activities, channeling specific information about past and present affairs as well as giving an indication of future objectives. Numbers play a crucial part in defining an organization's image. This makes financial statements a contested terrain and points to the political nature of standards, which are at the heart of financial reporting and auditing.

Although discussions about nonfinancial and future-oriented reporting are on the rise (cf. Chahed, 2011), most attention is still given to the numerical composition of the financial reporting framework. At the national level, the rules for drafting, presenting, and auditing annual reports were once commonly shaped in an interplay of professional actors, academics, accounting practitioners, lawmakers, and business interest groups. Financial statements used to reflect historical traditions, cultural backgrounds, socioeconomic conditions, and the balance of political power. Today, the increasing role of the IASB contributes to detaching accounting standardization from existing national traditions. While implementation and enforcement largely remain local affairs, the development of quasi-binding standards is orchestrated transnationally by the IASB. To a considerable degree, the locus of rule making has shifted, and standardization has become disembedded and detached from long-standing national contexts.

Much of today's interest in the IASB is rooted in this unique setup of accounting standardization. Its effective consultation procedures, the assemblage of renowned individuals and organizations, and a selfconfident display of professional expertise make the organization a "successful" case of private cross-border rule-making. As will be shown in Chapter 3, a historical perspective reveals that for more than 25 years the 
IASB's prospects were unclear. Developments were blocked by opposing interests and a lack of recognition by third parties impeded significant progress. For years, the absence of public authority was an impediment to effective transnational regulation. A closer look suggests that, for a considerable time, the emergence of a private rule-setting arrangement seemed unlikely. Consequently, the fact that the IASB has emerged as the dominant standard setter not only calls for empirical explanation but also provides a vantage point for theoretical considerations. Understanding how IASB became a "strategic networker, seeking to entrench its standards in the operations of other key actors" (Braithwaite and Drahos, 2000, p. 121) will contribute to getting a better picture of transnational self-regulation and explaining institution building beyond the nation state. The book explicitly links norms, organizational structures, and actor constellations to reconstruct how a coalition of actors established, reformed, and solidified a private standard-setting organization that today sets the tone in the field of accounting regulation. Conceptually, the book provides generalizable findings with regard to the mechanisms of transnational institution building.

The book is structured as follows: Chapter 1 provides an introductory overview of the globalization of accounting. It also points out the societal dimensions of accounting rules and discusses the global spread of IAS/IFRS. Chapter 2 gives an outline of central theoretical approaches to explain transnational accounting standardization and presents the research design and methodology. Chapter 3 gives a condensed account of the IASB's origins and early history, underlining that contest over the means and goals of the organization has been prevalent from the beginning. By putting the private regulatory arrangements into historical context, I indicate how the IASB managed to outcompete public endeavors to make international rules by drawing on anti-statist professionalism. Chapter 4 analyzes changes in the normative content of accounting standards, in particular the increasing capital-market orientation embodied in fair value accounting. It becomes clear that accounting standards are both a result of and a further force driving financialized global capitalism. Chapter 5 reconstructs the organizational developments of the IASB and uncovers how the privately run standard setter established procedures to consult with interested parties without handing over too much influence to outsiders. The analysis shows how democratic accountability was subordinated to the effectiveness of expertise-based standardization largely driven by - private and public - Anglo-American actors. Chapter 6 complements the organizational dimension with an analysis of the dominant individuals and the most influential organizations in the wider international standardization network. Accountants and globally active auditing firms 
accompanied by national regulators and selected international organizations dominate standard setting. Surprisingly, users of financial statements, by many considered to be the prime addressees of those statements, do not play a significant role. Finally, Chapter 7 sums up the empirical findings and relates them to the theoretical debates on transnational institution building, interpreting the developments as the emergence of a transnational regulatory path.

In a nutshell, the book argues that standardization is much more than a "technical" affair orchestrated by a few dedicated individuals striving to find the one best solution in international standardization. Instead, the politics of accounting regulation shows that economic globalization is constructed by many actors and succeeds when carefully linking the normative content of standards to organizational structures, consultation procedures, and stable actor coalitions. This explains how, even in times of financial crisis, the IASB displays remarkable institutional stability and continues to shape financial reporting practices worldwide.

\subsection{THE SOCIETAL RELEVANCE OF FINANCIAL REPORTING: THE POLITICS OF ACCOUNTING REGULATION}

The objective of publishing financial statements is to give an account of an entity's financial and economic activities. States, nonprofit foundations, cooperatives, and profit-making organizations all issue financial and nonfinancial information to inform shareholders, stakeholders, and other third parties. Organizations use formal annual reports to comply with legal requirements but also to conform to more general norms of accountability, reliability, and validity. For corporations, proper book keeping and transparent reporting are key elements in any strategy to disseminate information regarding their current state and future prospects. Financial statements serve to inform market actors and public authorities and assist them in making decisions, such as buying or selling shares, granting loans or purchasing products. Individuals might base their job search on the information published while tax authorities draw on accounts to levy taxes. The information function of financial statements, however, is contextualized in time and space and subject to change.

Depending on the national context and the particular legal status of a corporation, the groups to which financial reporting information is addressed will vary: In Anglo-American countries, shareholders and investors are considered the most relevant target group for the financial statements issued by listed companies. In continental Europe, annual reports 
also serve tax authorities, which have traditionally used them to determine the taxes of profit and nonprofit entities. Over time, the orientation toward anonymous outsiders, namely the providers of capital, has increased in many jurisdictions. This is symbolized by a shift in vocabulary from "accounting" to "financial reporting." While the former stresses the recording, classifying, and summarizing of financial transactions and events, reporting puts more emphasis on formally presenting corporate affairs to investors. The preparation of financial statements encompasses both accounting for past periods and depicting reasonable expectations for the future. As well as practitioners, many accounting scholars suggest or at least imply that the information disclosed in financial statements is an "objective" representation of a company's economic situation. Such a positivist understanding dominates institutional economics, particularly transaction cost and positive accounting theory. Interpretative accounting theory, institutionalist research, and radical accounting theory, on the other hand, have challenged this view. Most of the literature on accounting in the fields of sociology and political economy is in line with the latter approaches and rejects assumptions that economic reality can be objectifiable, or easily transposed into numbers. Instead, drafting a financial report is a constructive act in which numerical and other data are assembled by both following and interpreting existing accounting standards. This latter view is the basis of this book, which shares the assumptions of post-positivist theories.

More critical approaches also allow consideration of the distributive effects induced by accounting standards. Today, the most pertinent aspect of financial statements is to determine a corporation's profit or loss, which in turn serves as the basis for determining dividends and management remuneration. Corporate results are also processed by financial market actors and influence credit lines, ratings, and the stock market valuation of the reporting entity. These distributive effects make accounting standards a worthwhile target of different interest groups: Whenever national or international standard-setting bodies

formulate accounting rules, governmental and quasi-governmental agencies, companies preparing financial statements, financial analysts and investment advisors, auditors and tax advisors, employees' representatives, accounting professors, lawyers, and other affected parties all make their influence felt. They propose changes or defend the status quo, comment on suggestions of others, wield knowledge, money, and other instruments of power-all this to promote accounting rules that are as favourable to them as possible. (Ordelheide, 2004, pp. 271ff.)

Both at the national and international level, lobbying activities have been analyzed as part of an overt conflict over the precise wording of particular 
standards (Cooper and Robson, 2006, pp. 426ff.). This political dimension remains one important aspect of standardization that is more than the "technical" quest for the one best solution. This is why, in this book, I extend the view beyond the first dimension of power (cf. Lukes, 1974) and investigate the institutional rules of the game, which determine how and by whom international accounting standards are set. The analysis follows a research tradition that regards organizational and institutional practices as core features of financial accounting (cf. Hopwood and Miller, 1994; Chapman et al., 2009).

Harmonization is a central element of profit distribution because it gives preference to one paradigm. The vast differences between previously coexisting accounting approaches become clear when considering the variation in corporate results as a consequence of applying the respective standards. The most prominent example of large discrepancies between German and US accounting standards is Daimler-Benz's financial statement of 1993. Being listed on the New York Stock Exchange, the carmaker is required to produce earnings figures according to US generally accepted accounting principles (US GAAP). In 1993, those figures showed a loss of DM1.8 billion. For the same year, group accounts prepared in line with the German Commercial Code disclosed a profit of DM615 million (Glaum, 2000, p. 37). First and foremost, the discrepancies irritated analysts and investors, and practitioners frequently used them to underline the need for globally harmonized standards in financial accounting. As will be shown in Chapter 3, accounting's embeddedness in wider socioeconomic relations, expressing specific national and historical conditions, is to be reckoned with when trying to harmonize standards.

Daimler-Benz and its 1993 financial report was an exceptional case. As a rule, German corporate accounts used to be tightly coupled to the legal and tax system. In general, this favored income smoothing and setting up liability reserves. In financial market-oriented countries (or outsider systems), the presentation of favorable economic results tends to positively influence the share price. Whereas in Germany displaying high profits potentially leads to higher taxes, the US system favors claiming higher profits and dividends, and thus contributes to short-termism and outsider control (cf. Hall and Soskice, 2001). In this regard, changes in Germany are only one example of a more profound shift in socioeconomic configurations. Some ten years after the Daimler-Benz example quoted above, the transformation from the "old" accounting regime defined by the German Commercial Code to a "new" arrangement in accordance with European and international standards resulted in a substantial overall increase in profits merely by applying different standards. A study 
by the investment bank Sal. Oppenheim shows that the introduction of IAS/IFRS in Germany led to a substantial rise in corporate profits. The shift to international standards in 2004 and 2005 boosted net profits declared by the 30 biggest listed companies in Germany by between 10 and 15 percent. Goodwill accounting and the financial reporting of pensions have significantly contributed to the increase; the trend toward allowing discretion in recognition and measurement as well as the move toward fair value accounting were particularly important. The study also points to the procyclical nature of market-oriented valuation: "In the event of an upswing, the new accounting principles mean significantly higher earning with increasing momentum and volatility" (Sal. Oppenheim, 2007). In the financial crisis this volatility became evident.

Another incompatibility between "old" German and "new" international standards became evident in distinguishing between debt and equity. Amendments to IAS 32 Financial Instruments (puttable instruments) were criticized as being insufficient to cover the practical requirements of German partnerships (DRSC, 2005, p. 8). In effect, adopting the international definition of "equity" would have meant that substantially more capital would need to be attracted than under the previous arrangement, which was more favorable to insiders and owners. Consequently, a German interpretation of IAS 32 was issued to address specific circumstances related to German company law, which are particularly important for partnerships and cooperatives (DRSC, 2008, p. 62). As the latter constitute one of the core pillars of the German banking system, what may seem to be a minor detail on first glance has huge implications for the economy as a whole. This led to the diffusion of IAS/IFRS in Germany being interpreted as the introduction of formerly alien norms that have the potential to "Americanize" German corporate law through strengthening capital market logics (Lütz and Eberle, 2008). Even though apparently technical in nature, IAS/IFRS are far more than mere classifications or neutral rules for financial reporting. They spur an orientation toward financial indicators and drive the marketization of corporate relationships, including the strengthening of outsider control and short-termism (Deeg, 2001, 2010; Volmer et al., 2007). This paves the way for an increase in management pay since executive compensation is increasingly tied to corporate performance and the stock market value of the firm (Lazonick and O'Sullivan, 2000; Boyer, 2007); a trend some German actors welcomed even though - or perhaps because - it implied a rupture with previous traditions.

More fundamentally, the relevance of standardizing financial reporting extends beyond the presentation of corporate results. Accounting rules are constitutive for the current economic system as a whole: 
Accounting is a societal institution. [. . .] Accounting is concerned with nothing less than the conceptualization of capital, its concrete expression in numbers, as well as budgeting and monitoring, and thus with a societal institution that is so central to our economic system that it has given it its name. Even though we speak of the "market economy," it is evident that the rules by which capital or income are determined are among the central institutions of our economic system. These rules are politico-economic because they are means by which societal groups can alter or improve their economic situation. (Ordelheide, 2004, p. 269)

Changes in accounting standards also reflect more profound developments in modern society. The audit explosion has affected all spheres of individual and organizational life (Power, 1994, 1997; Porter, 1995). Against the background of numerical abstraction as a means of "governing at a distance" (Rose and Miller, 1992), the societal impact of international accounting standards is increasingly becoming an area of investigation. The introduction of IAS/IFRS leads to significant changes in the socioeconomic "calculation regime" (Biondi and Suzuki, 2007, p. 590). In particular, the introduction of market values through fair value accounting (FVA) encourages capital providers to adjust their decisions based on values expressed in prices or models (cf. Power, 2010). Even though FVA's precise effects are not yet sufficiently understood, general trends are visible: Short-termism gains weight, the bargaining position of labor is weakened, and capital markets become core institutions for economic coordination and exchange (Perry and Nölke, 2006, p. 574). In this context, international accounting standards are a product as well as a driver of financialization (cf. Froud et al., 2000; Epstein, 2005; Krippner, 2005). Building on the above-mentioned perspective of a "politics of accounting," the dynamics and struggles of establishing a regulatory arrangement to set globally accepted standards point to a need for a new analytical dimension: The institutional setting in which IAS/IFRS are defined. This book sheds light on this particular aspect of transnational standardization by analyzing the politics of accounting regulation.

\subsection{THE GLOBAL DIFFUSION OF INTERNATIONAL ACCOUNTING NORMS}

The dissemination of harmonized standards is a foundation of the global mobility of capital and the growing importance of organized capital markets, that is, stock exchanges. This renders the relatively late diffusion of the IASB's standards in the first decade of the twenty-first century particularly noteworthy. For three decades, the IASB and its predecessor 
have produced rules that had only very limited impact. Despite this, many functionalist perspectives attribute the IASB's emergence and success to the usefulness of its standards. While, today, the dissemination of IAS/ IFRS is impressive, far-reaching implementation of the standards does not explain how this historical development came about. Instead, explaining the IASB's genesis requires an organizational perspective. Current success is not the result of the diffusion of the standards; rather, the diffusion of the standards is the product of organizational and political decisions, which laid the foundations for their success.

Harmonized standards allow a comparison of corporate performance and are said to be used for investment decisions worldwide. A closer look at the origins of IAS diffusion patterns, however, shows that initially private actors did not play a central role in adopting the standards. Instead, formal adoption of IAS first occurred outside the developed world in countries such as Guatemala (2002), Jamaica (2002), and Tadzhikistan (2002) under pressure from international organizations (Cooper and Robson, 2006, p. 421). Some countries, such as Tanzania (2004), even introduced IAS for both listed and nonlisted companies, effectively replacing the local standards with internationally drafted rules. The breakthrough for IAS/IFRS came when the European Union issued a regulation requiring the adoption of IASB's standards from 2005 onwards. As early as 1995, the European Commission argued for the adoption of IAS to impede European multinationals from submitting to US accounting standards (EC, 1995). For a long time, private corporations were reluctant to voluntarily adopt IAS. When they did do so, corporations based in France, Germany, and Switzerland mostly issued IAS-based reports in addition to those required by national legal provisions.

Early diffusion of IAS/IFRS was characterized by bringing nonAngloAmerican jurisdictions in line with capital market logic. Peripheral countries, such as developing nations or post-Soviet states, were the first to adopt IAS/IFRS to modernize their national standards, under pressure from the IMF, the World Bank, or the World Trade Organization (WTO). These organizations succeeded in calling for more transparent accounting standards after economic crises, such as the Asian financial crisis of 1997-98. Weak accounting and reporting standards, and poor auditing practices, were considered core problems, and government officials of the $\mathrm{G} 7$, representing industrialized countries, gave the IASB's predecessor "an official mandate from national governments and protected the Committee [the IASB's predecessor] against competition from existing and potential rivals" (Martinez-Diaz, 2005, p. 13). Furthermore, leading international financial institutions, such as the IMF and the World Bank, took advantage of the Asian crisis to incorporate IAS/IFRS into their political goals 
and policies. The World Bank was particularly engaged and demanded that IAS be integrated into the disclosure requirements of borrowers (cf. Neu and Ocampo, 2007). "Also, the Bank increased the number of accountants on its staff to 125 by the mid-1990s to help borrowing states produce financial reports compliant with IASC standards" (MartinezDiaz, 2005, p. 14).

Another reason for introducing IAS is related to the extension of accountancy services, which was discussed in the General Agreement on Trade in Services (GATS) and the WTO. Already in the 1990s, European representatives of the accounting industry (Fédération des Experts Comptables Européens, FEE) proposed expanding trade in accountancy services:

The US government subsequently submitted two proposals for an accountancy annex that included many of the ideas put forward by the FEE and the US accounting industry, including requests for (1) procedures and guidelines to promote mutual recognition of professional qualifications, (2) recognition of the role of the International Accounting Standards Committee (IASC) in developing international financial reporting standards, and (3) recognition of the International Federation of Accountants' (IFAC) role in developing international standards and guidelines. (Arnold, 2005, pp. 310ff.)

The accountancy profession has discussed the advantages and drawbacks of cross-border comparability of national accounting standards for more than 100 years. From the beginning, easing transatlantic capital flows was an important dimension in this endeavor, which US and British accountants developed into a profitable business (cf. Samuels and Piper, 1985; Daniels et al., 1989). Early on, professional associations were particularly active and used international congresses to discuss accounting issues. The 1st World Congress of Accountants took place in St. Louis in 1904 and was dominated by Anglo-American professionals, who traditionally have taken a critical stance toward the role of public authorities in setting standards in accounting and auditing (Willmott et al., 2000).

In 1973, the establishment of the IASB's predecessor, the IASC, marked the initiation of a formalized standard-setting process. Chapter 3 shows that the organization immediately commenced its standard setting activities. While the formal adoption of IAS/IFRS took almost three decades, even voluntary application by some multinational corporations from continental Europe took at least 15 years. Research indicates that nonlocal standards were seldom applied in Europe. Cuijpers and Buijink (2005, p. 494) find that in 1999 out of over 1600 European firms (excluding the UK and Ireland) less than 7 percent opted for nonlocal standards, that is US GAAP or IAS. All in all, they conclude: 
We find that the rate of adoption of non-local GAAP by non-financial firms domiciled and listed in the EU in 1999 is relatively low. Apparently, voluntary adoption of IAS or US GAAP brings no net economic benefits for a large majority of firms. However, we find that adopters of non-local GAAP have some common characteristics that discriminate them from non-adopters. Firms that use non-local GAAP are more likely to be listed on a US exchange or the EASDAQ exchange, have more geographically dispersed operations, and are larger on average than firms using local GAAP. (Cuijpers and Buijink, 2005, p. 518)

The later indications underline the importance of using IAS/IFRS, particularly for big corporations aiming to achieve crossborder listing and improve their reputation with international investors. Interestingly, Cuijpers and Buijink do not find evidence of a lower cost of capital for these adopters (2005, p. 518). Instead, the use of IAS might primarily aim to generate legitimacy for internationally active corporations wanting to demonstrate their fondness for the Anglo-American rules. In France, the proportion of the largest 100 companies using nonlocal standards at no time between 1985 and 2000 exceeded 40 percent. Concluding their study, Stolowy and Ding (2003) observe that French firms were eager to address the information needs of international actors but also considered political developments. They "observed the existence of a certain degree of opportunism by these groups, and a constant cost-benefit trade-off, determined not only by developments in French accounting regulations, but also by the changing power balance between the IASC and the SEC-FASB" (Stolowy and Ding, 2003, p. 196).

In sum, initial diffusion of IAS/IFRS in the early 2000s was predominantly secured by public actors and was not driven by corporations actively applying the rules. Consequently, in their own documents of the late 1990s, IASB referred to a number of - mostly public - actors when discussing the introduction of IAS around the world. At the time, private corporations played only a minor role:

International Accounting Standards have done a great deal both to improve and to harmonise financial reporting around the world. They are used: (a) as a basis for national accounting requirements in many countries; (b) as an international benchmark by some countries that develop their own requirements (including certain major industrialised countries, regional organisations such as the European Union, and an increasing number of emerging markets such as China and many other countries in Asia, Central Europe and the countries of the former Soviet Union); (c) by stock exchanges and regulatory authorities that allow foreign or domestic companies to present financial statements in accordance with International Accounting Standards; (d) by supra-national bodies that rely on IASC to produce accounting standards that improve the quality of financial reporting and the comparability of financial statements, 
instead of developing their own requirements; (e) by the World Bank Group and other development agencies that require borrowers and recipients of other forms of aid to follow high standards of financial reporting and accountability; and (f) by a growing number of individual companies. (SWP, 1998, pp. 3ff.)

A more detailed characterization of the genesis of the IASB's standards is given in the later sections of this book, specifically in Chapter 4. At this point, it is important to stress the more general trends in the IAS/IFRS success story: The diffusion of standards happened only after a coherent, capital market-oriented set of rules had been developed and-as will be shown in Chapter 5-after the IASB modeled its organizational structure after the US standard setter. The global dissemination of IAS/IFRS therefore does not explain the IASB's development to become the sole transnational standard setter in accounting. Today, however, the IASB's influence extends far beyond listed companies in industrialized countries. The standard setter is eager to expand the reach of its norms to small and medium-sized companies (SMEs) and even nonprofit organizations. Remarkably, some IASB members consider it common sense that the basic assumption of decision usefulness of IAS/IFRS is even applicable to organizations that are not publicly listed and have no intention to go public. The normative foundations embodied in IASB's standards nevertheless cater almost exclusively to the information needs of capital market actors. Fair value accounting is as much a rationale for the preparation of corporate financial statements as it is characterized by the "self-generated, even missionary nature of pressures to reform" (Power, 2010, p. 208). As such, FVA is closely related to the rise of the IASB, the dominance of professionals and experts, and to the formation of identity for those working in standardization (Power, 2010, p. 206).

Equally remarkable is how international accounting standards, despite open criticism, have weathered the storm brought about by the global financial crisis of 2008. While crises have always been an important catalyst for redrafting financial market regulations (cf. Kindleberger, 2000), recent legal reforms in the USA have primarily aimed at introducing stricter controls on the application of accounting rules and auditing requirements. The rule setting procedures, however, have remained largely untouched. Neither the Sarbanes-Oxley Act of 2002 nor the Dodd-Frank Act of 2010 put accounting standards into the limelight. The emphasis is on misuse of existing rules instead of the problematic nature of the rules as such (cf. Froud et al., 2004). The reaction to the financial crisis is covered in more detail in Chapter 4, but at this stage it can be said that, at large, the IASB's success remains unchallenged. More than 100 jurisdictions permit or require IAS/IFRS for domestically listed companies, among 
them the European Community, Australia, and Brazil. About 90 countries have fully conformed to the standards; others, including Canada and Korea, are expected to complete transition to IAS/IFRS in 2011. Mexico and Argentina will require IAS/IFRS for all listed companies in 2012, and Japan has introduced a roadmap for adoption for 2015 or 2016. Pending the SEC's decision to adopt IAS/IFRS in 2011, listed companies in the USA could be required to use the international standards starting 2015 (cf. AICPA, 2011; IASplus, 2011a).

Despite IASB's dominance today, the relatively late diffusion of IAS/ IFRS points to an underexposed aspect of transnational standardization: The standard setting organization emerged over many years, but the diffusion of its standards happened at a relatively late stage in the process. What therefore needs to be explained is how a standardization arrangement developed and stabilized over a period of more than three decades while its regulatory output has only recently found acceptance. To answer that question, this book discusses in detail how a private rule-setting arrangement has successfully managed its transition from a nonbinding professional project to a quasi-global standard setter. To be able to understand the development, I draw on theoretical concepts focusing on transnational standardization in accounting studies, political economy, and sociology, which are discussed in the next chapter.

\section{NOTE}

1. IASB changed its name in 2001 when the International Accounting Standards Committee (IASC) was restructured and renamed. The organizational changes are treated in depth in Chapters 3 and 4. In this introduction, the abbreviation IASB is used for ease of reading even when covering the period before 2000 . 